\title{
A prospective observational study of breech pregnancy in a tertiary care centre
}

\author{
Somika Kaul, Bijal D. Rami*
}

Department of Obstetrics and Gynecology, Baroda Medical College, Baroda, Gujarat, India

Received: 26 November 2019

Revised: 24 December 2019

Accepted: 31 December 2019

\author{
*Correspondence: \\ Dr. Bijal D. Rami, \\ E-mail: bijalrami323@yahoo.com
}

Copyright: () the author(s), publisher and licensee Medip Academy. This is an open-access article distributed under the terms of the Creative Commons Attribution Non-Commercial License, which permits unrestricted non-commercial use, distribution, and reproduction in any medium, provided the original work is properly cited.

\begin{abstract}
Background: Breech presentation is the commonest of all mal presentations. Vaginal delivery of breech presentation at term is associated with a much higher perinatal mortality and morbidity than that of vertex presentation.

Methods: This prospective study was carried out in the department of obstetrics and gynaecology, S. S. G. Hospital, Baroda for a period of six months from $1^{\text {st }}$ May 2019 to $31^{\text {st }}$ October 2019. Out of a total number of 4476 deliveries, 159 were breech pregnancy. It included all the women admitted in labour room or ward who delivered with clinical or ultrasound diagnosis of breech presentation after 20 weeks of gestation.

Results: In the present study incidence of breech pregnancy was 3.6\%. Authors observed the highest incidence of breech pregnancy in the age group of 20 to 25 years. Maximum (62.9\%) cases delivered after 37 weeks of gestation. In our study $62.3 \%$ cases were primigravida and $37.7 \%$ were multigravida. Majority of cases (77.4\%) delivered by caesarean section. Among all the babies born 50.6\% were having birth weight of less than $2.5 \mathrm{~kg}$.

Conclusions: Authors need to study and analyse all cases of breech pregnancy individually to decide the management and mode of delivery depending on cases to case basis and expertise of the staff available. Delivery of breech foetus should be conducted by experience obstetrician after appropriate consent from pregnant women and her relatives.
\end{abstract}

Keywords: Breech presentation, Caesarean section, Maternal outcome, Mode of delivery, Perinatal outcome, Vaginal delivery

\section{INTRODUCTION}

Breech presentation is commonest malpresentation with an incidence of $3-4 \%$ at term. Incidence is about $20 \%$ at 28 weeks of pregnancy and drops to $5 \%$ at 34 weeks. ${ }^{1}$ Common etiological factors associated with breech pregnancy are prematurity, multiple pregnancy, congenital foetal and uterine malformation, foetal growth restriction, contracted pelvis, placenta praevia etc. ${ }^{2}$ The management of breech delivery continues to be debatable.

In 2015 recent Cochrane review published more than $90 \%$ reduction in perinatal mortality and neonatal morbidity in a planned caesarean section. ${ }^{3}$ In 2000 Lancet published the results of term breech trial. This clearly concluded that planned caesarean section is better than planned vaginal birth for the term foetus with breech presentation in terms of neonatal outcomes. ${ }^{4}$

However, an attempt to improve the neonatal outcome has resulted in the following effects as well. Firstly, there has been decline in the number of obstetricians able to conduct a vaginal breech delivery and it has also resulted in higher caesarean section rate and its complications.

To conclude there is a need to evaluate above observations in the context of available resource settings. 


\section{METHODS}

This prospective study was carried out in the department of obstetrics and gynaecology, S.S.G. Hospital, Baroda for a period of six months from $1^{\text {st }}$ May 2019 to $31^{\text {st }}$ October 2019. The total number of confinements were 4476, out of which 159 were breech pregnancy.

\section{Inclusion criteria}

- Primigravida or multigravida

- Booked or unbooked cases

- Patients admitted in labour room or antenatal wards who delivered with clinical or ultrasound diagnosis of breech pregnancy after 20 weeks of gestation.

\section{Exclusion criteria}

- Patients with diagnosis of breech pregnancy at 20 or less than 20 weeks of gestation.

A detailed study of all cases was done. Each patient was asked for detailed menstrual and obstetric history, history regarding antenatal care and number of visits. A careful general physical examination and systemic examination was carried out in all the patients. Per-abdominal examination included fundal height, abdominal girth, foetal presentation, engagement, foetal heart sounds and uterine contractions. Per-vaginal examination was done and position, effacement and dilatation of cervix was noted. Presence of bag of membrane, presenting part, station and adequacy of pelvis was also noted. Routine investigation like haemoglobin, urine sugar, urine albumin was done. Women having obstetric indication for caesarean section like foetopelvic disproportion, hyper extension of foetal head, footling presentation and associated medical complications were assigned to the caesarean section group. Plan of delivery was discussed with patients and attendants. Trial of vaginal delivery was given to the patients who gave consent for the same.

\section{Statistical analysis}

The data obtained was analyzed and then presented in simple descriptive statistics using tables after collection. The results were presented as number and percentages. The analyzed data was further compared with different studies and discussed thereafter.

\section{RESULTS}

This study includes 159 cases of breech pregnancy to study maternal and neonatal outcome.

Table 1 shows that the incidence of breech pregnancy was highest (69.2\%) between 20-25 years of age group, as in India maximum number of women who conceive fall in this age group because of early marriage and early pregnancy. After age of 30, incidence of breech pregnancy decreases because lesser number of females conceive after age of 30 .

Table 1: Maternal age distribution.

\begin{tabular}{|lll|}
\hline Age (years) & Number of cases & $\%$ \\
\hline$<20$ & 8 & $5.0 \%$ \\
\hline $20-25$ & 110 & $69.2 \%$ \\
\hline $26-30$ & 32 & $20.1 \%$ \\
\hline$>30$ & 9 & $5.7 \%$ \\
\hline
\end{tabular}

Table 2 shows that maximum number of cases $(62.9 \%)$ delivered after 37 weeks of gestation. $11.9 \%$ of cases delivered before 34 weeks of gestation.

Table 2: Gestational age at time of delivery.

\begin{tabular}{|lll|}
\hline $\begin{array}{l}\text { Weeks of gestation } \\
\text { at delivery }\end{array}$ & Number of cases & $\%$ \\
\hline$<34$ & 19 & $11.9 \%$ \\
\hline $34-37$ & 40 & $25.2 \%$ \\
\hline$>37$ & 100 & $62.9 \%$ \\
\hline
\end{tabular}

Table 3: Distribution according to gravidity.

\begin{tabular}{|lll|}
\hline Gravida & Number of cases & $\%$ \\
\hline Primi & 99 & $62.3 \%$ \\
\hline Second & 38 & $23.9 \%$ \\
\hline Third & 14 & $8.8 \%$ \\
\hline Fourth & 4 & $2.5 \%$ \\
\hline Fifth & 3 & $1.9 \%$ \\
\hline Sixth & 1 & $0.6 \%$ \\
\hline Seventh & 1 & $0.6 \%$ \\
\hline
\end{tabular}

Table 3 shows that maximum number of patients $62.3 \%$ were primigravida. Out of all primigravida with breech pregnancy, $84.9 \%$ were delivered by caesarean section. While as, $71.1 \%$ of second gravida were delivered by caesarean section. This shows that caesarean section as a mode of delivery is much common in primigravida as compared to second gravida. Out of all multigravida, 38 were second gravida, 14 were third gravida, 4 were fourth gravida, 3 were fifth gravida, and one each were sixth and seventh gravida. The reason for breech presentation in multi gravida is poor tone of uterine musculature in multi gravida favouring malrotation and subsequent breech presentation.

Table 4: Distribution according to mode of delivery.

\begin{tabular}{|lll|}
\hline Mode of delivery & Number of cases & $\%$ \\
\hline Vaginal delivery & 36 & $22.6 \%$ \\
\hline LSCS & 123 & $77.4 \%$ \\
\hline
\end{tabular}

Table 4 shows that overall incidence of caesarean section in this study was $77.4 \%$ and of vaginal delivery was $22.6 \%$. Out of all caesarean deliveries $68.3 \%$ were primigravida, $22 \%$ were second gravida and $7.3 \%$ were 
third gravida. In addition, $41.7 \%$ of all vaginal deliveries were primigravida, $30.6 \%$ were second gravida and $13.9 \%$ were third gravida. Out of all 36 vaginal breech deliveries 21 were multigravida and 15 were primi gravida. So, patients with breech presentation in labour should be given trial for vaginal delivery especially if they are multigravida.

Table 5: Birth weight wise distribution.

\begin{tabular}{|lllll|}
\hline Baby weight & Number of cases & $\%$ & Vaginal delivery & Cesarean section \\
\hline$<2500 \mathrm{gm}$ & 84 & $50.6 \%$ & $20.2 \%$ & $79.8 \%$ \\
\hline $2500-3500 \mathrm{gm}$ & 79 & $47.6 \%$ & $25.3 \%$ & $74.7 \%$ \\
\hline$>3500 \mathrm{gm}$ & 3 & $1.8 \%$ & $33.3 \%$ & $66.7 \%$ \\
\hline
\end{tabular}

Table 6: Associated factors.

\begin{tabular}{|lll|}
\hline Factor & Number of cases & $\%$ \\
\hline Previous one caesarean section & 12 & $7.5 \%$ \\
\hline Intra uterine foetal death & 10 & $6.3 \%$ \\
\hline Anaemia & 50 & $31.4 \%$ \\
\hline Pregnancy induced hypertension & 11 & $6.9 \%$ \\
\hline Twin pregnancy & 5 & $3.1 \%$ \\
\hline Previous two caesarean section & 3 & $1.9 \%$ \\
\hline Antepartum eclampsia & 3 & $1.9 \%$ \\
\hline Sickle cell anaemia & 2 & $1.3 \%$ \\
\hline Premature rupture of membrane & 18 & $11.3 \%$ \\
\hline
\end{tabular}

Table 5 shows $50.6 \%$ of babies were having birth weight of less than $2.5 \mathrm{~kg}$. $47.6 \%$ of babies were having birth weight between 2.5 to $3.5 \mathrm{~kg}$. $79.8 \%$ of babies having birth weight of less than $2.5 \mathrm{~kg}$ were delivered by caesarean section and $74.7 \%$ of babies having birth weight of $2.5-3.5 \mathrm{~kg}$ were delivered by caesarean section.

Table 6 shows that in present study $31.4 \%$ cases were having anaemia, $7.5 \%$ were previous one caesarean section, $1.9 \%$ were previous two caesarean section, $6.3 \%$ cases were having intra uterine foetal death and $3.1 \%$ cases were twin pregnancy with first baby with breech presentation. No patients with history of previous caesarean section delivered vaginally. $11.3 \%$ of cases were having premature rupture of membrane. Out of total $6.9 \%$ of pregnancy induced hypertension cases $3.1 \%$ were having severe pregnancy induced hypertension and $3.8 \%$ were having mild pregnancy induced hypertension. Three cases of antepartum eclampsia and two cases of sickle cell anaemia were also noted. One case of triplet pregnancy was seen with first baby having breech presentation. One case each of maternal asthma, hypothyroidism and post-partum haemorrhage was noted.

\section{DISCUSSION}

Breech presentation is defined as a foetus in a longitudinal lie with buttocks or feet closest to the cervix. The percentage of breech deliveries decreasing with advancing gestational age from $22 \%$ of birth prior to 28 weeks of gestation to $7 \%$ of birth at 32 weeks of gestation and further to $1-3 \%$ of births at term. ${ }^{5}$ The incidence of breech pregnancy is $3-4 \% .^{1}$ In present study incidence of breech pregnancy was $3.6 \%$.

In our study the incidence of breech pregnancy was highest $(69.2 \%)$ in the age group of $20-25$ years. A similar conclusion was drawn in study done by Panda $\mathrm{R}$ et al, in which maximum $(47.4 \%)$ occurrence of breech pregnancy was seen in the age group of 20-25 years and the incidence was $47.5 \%$ in the same age group as per study done by Singh A et al.,

In our study most of cases $(62.9 \%)$ delivered at more than 37 weeks of gestation. In the study done by Singh A et al, $73.4 \%$ cases delivered between 37-42 weeks of gestation. Similarly, in the study done by Panda et al majority of cases $(78.35 \%)$ delivered at more than 36 weeks of gestation. ${ }^{6}$ In our study $37.1 \%$ cases delivered preterm before 37 weeks of gestation which correlates with a study by Ratna Panda et al6 where $35 \%$ cases delivered preterm.

In our study $62.3 \%$ cases were primigravida and $37.7 \%$ were multigravida. This result was similar to the study done by Kavita et al, where primigravida constituted $62 \%$ and Panda $\mathrm{R}$ et al were $52.56 \%$ cases were primigravida. ${ }^{6,8}$

In our study majority of cases $(77.4 \%)$ were delivered by caesarean section. Similar results were observed by Goffinet et al, were $77.8 \%$ cases were delivered by caesarean section and Hannah et al were $66.7 \%$ cases delivered by caesarean section. ${ }^{9,10}$ 
In our study $50.6 \%$ of babies were having birth weight of less than $2.5 \mathrm{~kg}$.

In our study cases with previous caesarean section were $9.4 \%$. In study done by Singh A cases with previous caesarean section were $11.3 \% .^{7}$

In our study $11.3 \%$ cases were having premature rupture of membrane which correlates with study by Panda et al $\mathrm{R}$ in which $9.2 \%$ of cases were having premature rupture of membrane. ${ }^{6}$

Vaginal breech deliveries provide us an opportunity to train obstetricians to conduct vaginal breech deliveries and also prevent uterine scar and its future complications. Caesarean section for breech presentation has been suggested as a way of reducing the associated perinatal problem. ${ }^{11}$ The final mode of delivery should be decided on case to case basis.

\section{CONCLUSION}

To conclude mode of delivery should be decided based on individual case and the training level of the available staff. Vaginal breech delivery should always be conducted after explaining all the benefits and risks involved to the cases and obtaining due consent from the pregnant female and her relatives. Also, whenever a trial of vaginal breech delivery is offered arrangement should be made for an emergency caesarean section in case of failure of vaginal delivery.

Funding: No funding sources Conflict of interest: None declared

Ethical approval: Not required

\section{REFERENCES}

1. Dars S, Malik S, Bhurgri A. Is breech still being delivered vaginally? A comparative study. Int J Reprod Contracept Obstet Gynecol. 2014;3(1):144-8.

2. Mishra R, Malpresentations. In: Mishra R, eds. Ian Donald's Practical obstetric problems. $7^{\text {th }}$ ed. Wolters Kluwer. 2014:514-26.
3. Bin YS, Roberts CL, Ford JB, Nicholl MC. Outcomes of breech birth by mode of delivery: a population linkage study. Aus New Zealand J Obstet Gynaecol. 2016;56(5):453-9.

4. Hannah ME, Hannah WJ. Planned caesarean section versus planned vaginal birth for breech presentation at term: a randomized multicentre trial. Lancet. 2000;356:1375-83.

5. Hickok DE, Gordon DC, Milberg JA, Williams MA, Daling JR. The frequency of breech presentation by gestational age at birth: a large population-based study. Am J Obstet Gynecol. 1992;166(3):851-2.

6. Panda R, Jena P. A study on fetomaternal outcome of breech presentation in a tertiary care hospital. J Med Sci Clin Res. 2016;6(12):703-8.

7. Singh A, Mishra N, Dewangan R. Delivery in breech presentation: The decision making. J Obstet Gynecol India. 2012;62(4):401-5.

8. Kothapally K, Uppu A, Gillella V. Study of the obstetric outcome of breech presentation in pregnancy in a tertiary hospital in a rural area in Telangana, India. Int $\mathbf{J}$ Reprod Contracept Obstet Gynecol. 2017;6:2040-3.

9. Goffinet F, Carayol M, Foidart JM, Alexander S, Uzan S, Subtil D, Breart G. Is planned vaginal breech delivery for breech presentation still an option? Am J Obstet Gynecol. 2006;194(4):1002-11.

10. Hannah ME, Hannah WJ. Planned caesarean section versus planned vaginal birth for breech presentation at birth: a randomized multicentric trial. TBT collaborative group. Lancet. 2000;356(9236):137583.

11. Venditelli F Pons JC, Lemery D, Mamelle N. The obstetricians of the AUDIPOG Sentinel Network. The term breech presentation: Neonatal results and obstetric practices in France. Eur J Obstet Gynecol Reprod Biol. 2006;125:176-84.

Cite this article as: Kaul S, Rami BD. A prospective observational study of breech pregnancy in a tertiary care centre. Int J Reprod Contracept Obstet Gynecol 2020;9:688-91. 